\title{
Hemşire Akademisyenlerin Y Kuşağı Hemşirelik Öğrencileri Hakkındaki Deneyim ve Algıları: "Zor Öğrenciler"
}

\author{
Experience and Perceptions of Nurse Academicians on Generation Y Nursing Students: "Difficult Students"
}

\author{
Emre YANIKKEREM $^{1}$, Özge TOPSAKAL ${ }^{2}$, Aynur ÇETINKAYA ${ }^{3}$
}

\begin{abstract}
ÖZ
Araştırmanın amacı hemşire akademisyenlerin $\mathrm{Y}$ kuşağı hemşirelik öğrencileri hakkındaki deneyim ve algılarını betimlemektir. Tanımlayıcı nitel yaklaşım benimsenerek fenomenolojik desen ile yürütülmüş araştırmada; insan deneyimi doğal bağlamında açıklanmaya çalışılmıştır. Katılımcılar amaçlı örnekleme yöntemi kullanılarak araştırmaya katılmaya gönüllü olan 17 hemşire akademisyenden oluşmuştur. Araştırmanın verileri derinlemesine görüşmeler ile toplanmıştır. İçerik analizi yapılan görüşme metinlerinde hemşire akademisyenlerin ifadelerinden dört temaya ulaşılmıştır. En çok atıf alan tema etiketi zor ögrencidir. Diğer tema etiketleri sırasıyla $Y$ kuşağına uygun rol model hoca, hemşirelik eğitiminde engelleyici faktörler ve sorgulayan ögrrencidir. Öğrencilerin zor olduğu algısı (isteksiz, ilgisiz, internet odaklı çalışmayan) ve hemşirelik eğitimi için algılanan engelleyici faktörler (cinsiyet temelli engel algısı, teorik ve klinik uygulamada tutarsızlık ve çok sayıda öğrenci) var olan durumu betimlemede kullanılan tema etiketleridir. Hemşire akademisyenlerin beklentisi ise; sorgulayan öğrenci (araştırma ruhuna sahip olmak, güncel bilgi ve yenilikleri takip etmek, özgürlükçü) ve buna uygun rol model ögrretmen (güncel bilgileri yenilemek ve kendini geliştirmek, sorgulamak) şeklinde etiketlendirilmiştir. Hemşire eğitimciler, öğrencilerin kuşak özelliklerine benzeyen zorluğu dile getirmeleri yanında, kendilerine yönelik rol model eğitimci tanımlaması yapmışlardır. Dolayısıyla eğitimcilerin var olan durumla baş etmede yol gösterici yaklaşımları sunmaları araştırma konusuna 1 şı tutar niteliktedir.
\end{abstract}

Anahtar Kelimeler: Hemşirelik eğitimi, Niteleyici araştırma, Y kuşağı, Eğitici algısı

\begin{abstract}
The aim of the research was to describe the experiences and expectations of nurse academics about the generation $\mathrm{Y}$ nursing students. In the research carried out with the phenomenological pattern by adopting the qualitative descriptive approach; human experience has been tried to be explained in its natural context. The participants consisted of 17 academicians who volunteered to participate in the research using the purposeful sampling method. The data of the study was collected through in-depth interviews. In the interview texts with content analysis, four themes were reached from the statements of nurse academicians. The most cited theme label was difficult student. Others were role model teacher suitable for generation $Y$, barriers factors in nursing education, and questioning student, respectively. The perception that students were difficult (reluctant, uninterested, not studying, internet-oriented) and perceived barriers factors for nursing education (perception of obstacle gender based, theoretical and clinical practice inconsistency and high number of students) were the theme labels used to describe the current situation. The expectation of nurse academics; the questioning student (having investigative spirit, following current information and innovations, libertarian) and the appropriate role model teacher (renewing current information and improving himself, questioning). In addition to expressing the difficulty similar to the generation characteristics of the students, the nurse educators have defined themselves as a role model educator. Therefore, the fact that the educators present the guiding approaches in dealing with the existing situation sheds light on the research subject.
\end{abstract}

Keywords: Nursing education, Qualitative research, Y Generation, Perception of educator

\footnotetext{
${ }^{1}$ Doç. Dr., Emre YANIKKEREM, Doğum ve Kadın Hastalıkları Hemşireliği, Manisa Celal Bayar Üniversitesi Sağlık Bilimleri Fakültesi Hemşirelik Bölümü, emrenurse@ hotmail.com, ORCID: 0000000189093597

${ }^{2}$ Arş. Gör., Özge TOPSAKAL, Doğum ve Kadın Hastalıkları Hemşireliği Anabilim Dalı, Manisa Celal Bayar Üniversitesi Sağlık Bilimleri Fakültesi Hemşirelik Bölümü, ozgebydr_19@hotmail.com, ORCID: 0000000324436397

${ }^{3}$ Dr. Öğretim Üyesi, Aynur ÇETiNKAYA, Halk Sağlı̆̆ı Hemşireliği, Manisa Celal Bayar Üniversitesi Sağlık Bilimleri Fakültesi Hemşirelik Bölümü, aynur.cetinkaya@ cbu.edu.tr, ORCID: 0000000315990070
} 


\section{GİRIS}

Zaman içerisinde toplumlar sosyal, politik ve ekonomik birçok faktöre bağlı olarak değişim yaşayabilmekte yaşanan bu değişimler insanların değer yargılarını ve algılarını etkileyip değiştirebilmekte, bu değişimlerin oluştuğu zaman dilimleri de kuşak olarak adlandırılmaktadır., ${ }^{1,2}$ Alan yazında beş kuşak varlığından söz edilmektedir. Bunlar; 1925 - 1945 yılları arasında doğan Sessiz Kuşak sadık, otoriteye saygıll, disiplinli; Baby Boomers Kuşağ (1946 -1964) iş yerlerine bağl1, kuralcı, rekabetçi, çevreye duyarlı; X Kuşağı (19651979) çalışkan, özgüvenli, bağımsız, kanaatkâr, tedbirli, garantici, şüphecidir. Y Kuşağı 1980-1999 yılları arasında doğanları kapsamakta ve bu grup değişikliğe ve yeniliğe açık, dışa dönük, teknolojiye hakim ve meraklı, sabırsız, sadakat duyguları zayıf, kendine güvenen özelliklere sahiptir. 2000 y1lı ve sonrasında doğan Z Kuşağı antisosyal, zevkine düşkün ve teknolojiye hakim olup, ${ }^{2-}$ ${ }^{4} 2010$ yılından sonra doğan jenerasyon ise Alfa Kuşağı olup bu kuşaktaki bireyler aceleci, sabırsiz, uyumlu benmerkezci, girişimcidir. ${ }^{2,5}$ Kuşaklar arası farklılıklar nedeniyle her kuşak, kendinden önceki kuşakları "geri kafalı", "tutucu", "bağnaz" ve "çağ dışı" olarak nitelerken, kendinden sonraki nesilleri ise, "saygisız" ve "sorumsuz" olarak görebilmektedir. Bu nedenle kuşaklar arasında iletişim ve etkileşim bozuklukları, anlaşmazlıklar ve çatışmalar olabilmektedir. ${ }^{5}$

Son yıllarda kuşaklar arasındaki anlaşmazlıklar ve iletişim sorunları eğitim alanında da gündeme gelmiştir. Eğitimci ve öğrenciler arasında iletişim ve etkileşimin etkili olması öğrencinin özgüvenini, başarısını derse motivasyon ve ilgisini olumlu etkilemektedir. Bununla birlikte öğrencinin akademik başarısının artmasında ve öğrencilerde istenen davranışların geliştirilmesinde eğitimci ve öğrenciler arasında kurulan iletişimin önemli olduğu belirtilmektedir. ${ }^{5-6}$

Eğitimci ve öğrenci arasında sağlıklı ve etkili bir iletişimin kurulabilmesi için öğrencilerin eğitimcilerden beklentilerinin araştırılmasının önemli olduğu kadar eğitimcilerinde öğrencilerden beklentilerini ve deneyimlerini incelemek oldukça önemlidir. Yurtdışında yapılan çalışmalar incelendiğinde, Güney Afrika'da üç hemşirelik eğitimcisi ve 25 öğrenci ile sınıf içinde iyi etkileşim algıları grup görüşmesi ile nitel olarak tanımlanmış, eğitimcilerin öğrencilerden sayg1, dakiklik, dürüstlük ve dersleri aktif olarak dinlemelerini bekledikleri bulunmuştur. ${ }^{7}$ Amerika'da 24 hemşire eğitimci ile yapılan bir çalışmada eğitimciler başarılı öğrencileri öğrenmeye istekli, iyi ilişkileri olan, iletişimi iyi, kritik düşünebilen, klinik uygulama için hazır, ilerleme gösteren, geri bildirimi kabul eden ve klinik ortama uyum sağlayan öğrenciler olarak belirtmişlerdir. Bununla birlikte eğitimciler başarısız öğrencileri klinik uygulamalara hazır olmayan, klinik alanda çalışmayan, güvensiz, yasal-etik ilkeleri ihlal eden ve iletişim becerilerinde zorluk çeken öğrenciler olarak ifade etmişlerdir. ${ }^{8}$ Amerika'da 25 hemşire eğitimci ile yapılan diğer bir çalışmada başarısız öğrenci özellikleri incelenmiştir. İlk sırada öğrencinin iletişim problemi olduğu ikinci sirada ilerleme kaydedemediği bunu sırasıyla; hatalı ilaç uygulama, hasta bakımına öncelik verememe, derslere hazırlıksız gelme, sinıfin gerisinde olma, anksiyeteli olma, kendine güvenmeme ve profesyonel olmama takip etmiştir. ${ }^{9}$ On bir çalışmayı içeren bir bütünleştirici (integrative) literatür incelemesinde klinik ortamlarda kendine güveni olmayan hemşirelik öğrencilerinin özellikleri tanımlanırken etkisiz kişilerarası etkileşim, bilgi ve beceri yetersizliği ve profesyonel olmayan davranış temaları oluşturulmuştur. ${ }^{10}$ İngiltere'de 16 hemşire eğitimci ile yapılan bir çalışmada ise öğrencilerden beklenilen bilişsel özellik dürüstlük ve bilgi birikimi adlı iki temada, davranış özelliği ise klinik uygulamada kontrollü olma (bilgisi olmayan uygulamaları yapmama) ve klinik uygulamalarda titizlik ve hassasiyet adlı iki tema altında ele alınmıştır. $^{11}$ 
Türkiye'de hemşirelik öğrencilerinin akademisyenlerden beklentilerini araştıran birçok çalışma ${ }^{12-18}$ bulunmasına rağmen akademisyenlerin öğrencilerden beklentilerini araştıran sınırlı sayıda çalışmaya ulaşılmıştır. ${ }^{5,7,19-21} \mathrm{Bu}$ çalışmaların üç tanesi nitel yaklaşım ile planlanmış olup $^{7,20-21}$ diğer çalışmalar nicel tiptedir. ${ }^{5,19}$ Üniversitede İktisadi ve İdari Birimler Fakültesinde görevli 68 akademisyenle "Öğretmenlerin Y Kuşağı Öğrenci Özellikleri Algıları Ölçeği” kullanılarak yapılmış nicel bir çalışmada; X Kuşağı akademisyenlerin $\mathrm{Y}$ Kuşağ 1 öğrencilerin özellikleri ile ilgili genel olarak olumsuz bir algıya sahip olduğu ve öğrencilerin öğrenme kabiliyetlerinin yetersiz olduğu vurgulanmıştır. ${ }^{5}$ Bir Eğitim Fakültesi'nde ilk önce 9 öğretim üyesiyle yüz yüze görüşme yapılarak öğrencilerin performansını ölçmeye yararlı olacağı düşünülen 14 adet kriter (hazırlık, heveslilik, aktiflik, yeterlilik, performans, verimlilik, takiplik, keşfedicilik, nezaket-akademisyen, nezaket-arkadaş, iletişim, yabanc1 dil etkinliği, memnuniyet, başarı) belirlenmiş daha sonra bu kriterler göz önüne alınarak oluşturulan anketler diğer fakültedeki akademisyenler $\quad(\mathrm{n}=90)$ tarafindan yanıtlanmış; öğrencilerin performansına göre Analitik Hiyerarşi Süreciyle fakülteler sıralaması yapılmıştır. ${ }^{21}$ Sosyal bilgiler eğitiminde yaşanan sorunlara ilişkin akademisyenlerin $(\mathrm{n}=11)$ görüşlerinin alındığ 1 diğer bir nitel çalışmada öğrencilerin bölümü severek ve isteyerek gelmediği bu durumun öğrencilerde motivasyon kaybı ve derse ilgisizliğe yol açtığ belirtilmiştir. $^{20}$ Başka bir çalışmada Eğitim Fakültesinde görev yapan öğretim elemanları $(n=105)$ ögrencilerin interneti kullanabilme, derslere zamanında gelme, dersle ilgili düşüncelerini çekinmeden ifade edebilme ve birbirlerinin düşüncelerine saygılı olma özelliklerini yeterli bulmuşlardır. Öğretim elemanlarının öğrencileri yetersiz bulduğu özellikler kendilerine verilen kaynaklarla yetinmeyip başka kaynaklara başvurma, alan diş1 yayınları takip etme, derslere değişik yardımc1 kaynaklarla gelme, derslere hazırlıklı gelme, dersle ilgili materyalleri derslerde yanlarında getirme ve Türkçeyi yeterli düzeyde kullanabilmedir. ${ }^{19}$

Eğitimcilerin öğrencilerden beklentileri ile öğrencilerin davranışlarının birbirine uymadığı durumlarda çatışmaların yaşanması kaçınılmazdır. $\mathrm{Bu}$ çatışmaların bazıları eğitimcinin ve/veya öğrencinin kendi benliğinde yaşadığı rol çatışmalarından meydana gelebilir. İletişim ve etkileşim sürecinde gelişen yanlış anlamalar ve karmaşanın ortadan kaldırılması açısından, çatışma yaşayan iki tarafin birbirleri ile tamamlayıc1 iletişim ve etkileşim gerçekleştirebilmeleri önem taşımaktadır. ${ }^{5,22}$ Bir Devlet Üniversitesi Sağlık Bilimleri Fakültesi Hemşirelik Bölümü öğretim elemanları ile yürütülmüş bu nitel çalışma ile hemşire akademisyenlerin $\mathrm{Y}$ kuşağ hemşirelik öğrencileri hakkında deneyim ve algılarının betimlenmesi amaçlanmıştır.

\section{MATERYAL VE METOT}

\section{Araştırmanın Tipi}

Araştırma nitel araştırma desenlerinden kişinin öznel deneyimi ile ilgili çalışmalarda kullanılan fenomenolojik yaklaşım (olgu bilimi) ile yürütülmüştür. Hemşirelik bölümünde eğitim veren akademisyenlerin deneyim ve algılarını ortaya çıkarmaya yönelik yapılan bu araştırmada; tanımlayıcı nitel yaklaşım benimsenmiş ve deneyimler doğal bağlamında açıklanmaya çalışılmıştır. Nitel araştırma desenlerinin en önemli katkısı, araştırılan konuyu ilgili bireylerin bakış açılarından görebilmeye ve bu bakış açısını oluşturan sosyal yapıyı ve süreçleri ortaya koymaya olanak vermesidir. Fenomenolojik desen, kişinin öznel deneyimi ile ilgili olan ve yaşanılanlara odaklanan nitel araştırmaların kullandığ 1 yaklaşımlardan biridir. Olay, durum, deneyim ya da kavram gibi bir fenomeni aydınlatmaya çalışır. Bu yaklaşımı kullanan araştırmacılar şu soruları sorar: $\mathrm{Bu}$ insanların deneyimlediği olgunun özü nedir ve bu olgu ne anlama gelir? 
Fenomenolojik desende araştırmanın amacı yaşanmış deneyimleri ve bu deneyimlere neden olan algıları bütünüyle anlamaktır. ${ }^{23}$

\section{Araştırmanın Çalışma Grubu}

Bir Sağlık Bilimleri Fakültesi hemşirelik bölümünde eğitim veren ve eğitim ile ilgili deneyimleri ve öznel yaşantıları olan 1.,2.,3., ve 4. sinıflara ders veren öğretim üyesi ve öğretim elemanları çalışma grubu olarak belirlenmiştir. Çalışma grubundaki katılımcıların seçiminde amaçlı örnekleme yöntemi kullanılmıştır. Araştırmaya katılmaya gönüllü olan, fakültede hemşirelik bölümündeki her anabilim dalından bir öğretim üyesi ve öğretim elemanı çalışmaya alınmıştır. Farklı anabilim dallarından olmak üzere belirlenmiş hemşire akademisyenler ile görüşmelere başlanmış ve araştırma verileri doygunluğa ulaşıncaya dek hemşire akademisyenler ile görüşülmeye devam edilmiştir. Nitel araştırmalarda örneklem büyüklüğü için önerilen veri doygunluğu ölçüt olarak alınmıştır. Veri doygunluğu, nitel bir araştırmada bilginin niteliği ve niceliğini ifade eder. ${ }^{24}$ Ayrıca yeni bilgi ve yeni tema elde edilemediği nokta, verinin doygunluğunu gösterir. Veriler tekrarlamaya başladığında, 15. görüşmede doygunluk değerlendirilmiştir. Doyum noktasında net olabilmek için iki kişi ile görüşmelere devam edilmiş ve verilerin doyuma ulaştığına karar verilerek görüşmeler sonlandırılmıştır. Araştırma örneklemini dokuz anabilim dalından bir ögrretim üyesi ve bir öğretim elemanı olmak üzere araştırmaya katılmayı kabul eden 17 hemşire akademisyen oluşturmuştur (n:17). Bir anabilim dalı akademisyenlerinin başka bir okulda lisansüstü eğitim görmesi nedeniyle o anabilim dalından bir öğretim üyesi dahil edilmiştir.

\section{Araştırma Örnekleminin Özellikleri}

Katılımcıların tanıtıcı özelliklerine bakıldığında 17 hemşire akademisyenin tamamı kadındır. Yaşları 26-56 arasında değişmektedir. Hemşire akademisyenlerin 1 'i Profesör, 2'si Doçent, 5'i Dr. Öğr. Üyesi, 1'i Öğretim Görevlisi ve 8'i Araştırma Görevlisidir. Akdemisyen olarak çalışma süreleri 3 yıl ile 24 yıl arasında değişmektedir (Tablo 1).

Tablo 1. Örneklemin Tanıtıcı Özellikleri

\begin{tabular}{|c|c|c|c|c|}
\hline Katılımcı No & Yaşı & Cinsiyeti & Ünvanı & Çalışma süresi \\
\hline Katılımcı 1 & 31 & Kadın & Araştırma görevlisi & $5 \mathrm{y} 11$ \\
\hline Katılımcı 2 & 38 & Kadın & Dr. Öğr. Üyesi & $12 \mathrm{y} 1 \mathrm{l}$ \\
\hline Katılımc 3 & 28 & Kadın & Araştırma görevlisi & 6 y1l \\
\hline Katılımcı 4 & 30 & Kadın & Araştırma görevlisi & 5 y1l \\
\hline Katılımcı 5 & 36 & Kadın & Dr. Öğr. Üyesi & $10 \mathrm{y} 11$ \\
\hline Katılımcı 6 & 38 & Kadın & Dr. Öğr. Üyesi & 13 y1l \\
\hline Katılımcı 7 & 56 & Kadın & Profesör & 24 y1l \\
\hline Katılımcı 8 & 27 & Kadın & Araştırma görevlisi & 4 y1l \\
\hline Katılımcı 9 & 30 & Kadın & Araştırma görevlisi & 5 y1l \\
\hline Katılımc1 10 & 32 & Kadın & Araştırma görevlisi & 7 y1l \\
\hline Katılımc1 11 & 33 & Kadın & Öğretim görevlisi & 5 y1l \\
\hline Katılımc1 12 & 45 & Kadın & Dr. Öğr. Üyesi & $17 \mathrm{y} 11$ \\
\hline Katılımc1 13 & 45 & Kadın & Doçent & 23 y1l \\
\hline Katılımc1 14 & 50 & Kadın & Doçent & $17 \mathrm{y} 11$ \\
\hline Katılımc1 15 & 26 & Kadın & Araştırma görevlisi & 3 y1l \\
\hline Katılımc1 16 & 29 & Kadın & Araştırma görevlisi & $4 \mathrm{y} 1 \mathrm{l}$ \\
\hline Katılımc1 17 & 39 & Kadın & Dr. Öğr. Üyesi & 14 y1l \\
\hline
\end{tabular}




\section{Veri Toplama Araçları}

Araştırmada veri toplama aracı olarak yarı yapılandırılmış sorulardan oluşmuş görüşme formu kullanılmıştır. Formun ilk kısmında hemşire akademisyenlerin sosyo demografik özelliklerini içeren altı soruluk kısım ve ikinci bölümde alan yazın doğrultusunda hazırlanmış yarı yapılandırılmış yedi açık uçlu ana soru yer almaktadır. Bu sorular Tablo 2'de sunulmuştur.

Tablo 2. Yarı Yapılandırılmış Ana Görüşme Soruları

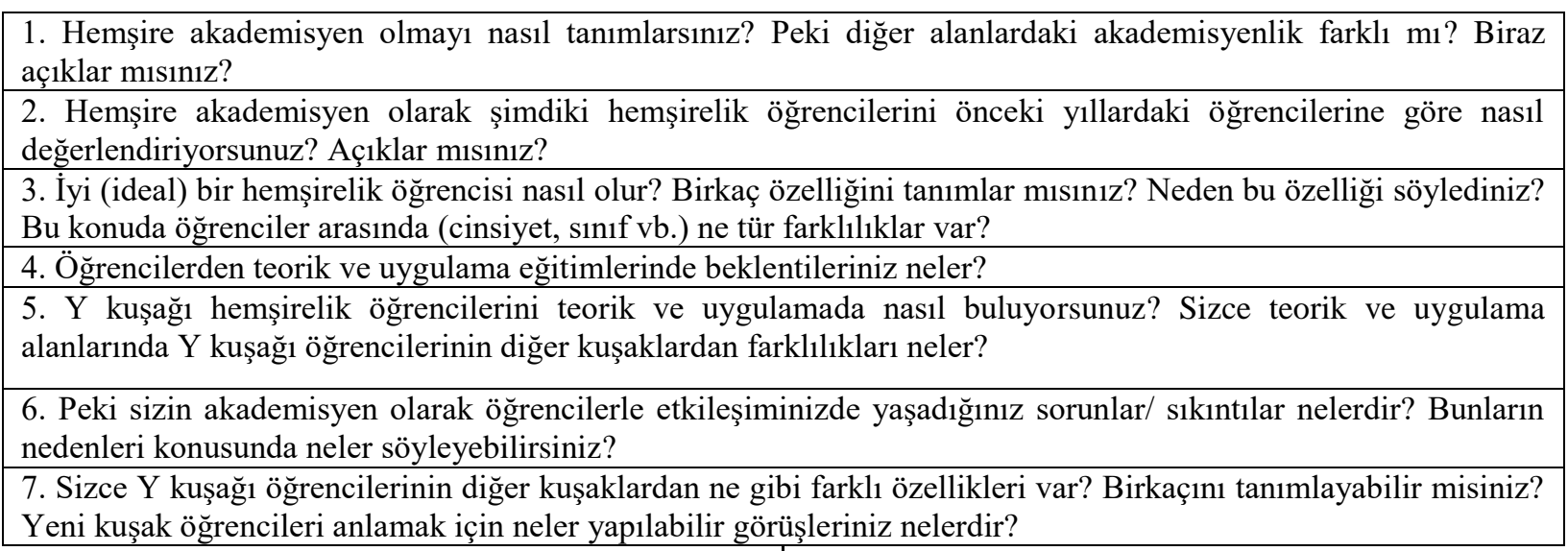

Önce "hemşire akademisyenlerin Y kuşağı hemşirelik öğrencileri ile yaşadıkları deneyimleri nelerdir ve $Y$ kuşağ hakkındaki algıları nasıldır?" sorusuna ilişkin alt problemleri saptamak ve akademisyenlerin deneyim ve algilarını derinlemesine ortaya çıkarmak için alan yazın doğrultusunda araştırmacılar tarafından açık uçlu sorular oluşturulmuştur. Daha sonra açık uçlu sorulara ilişkin nitel araştırma konusunda deneyimli ve hemşirelik alanında dört uzmandan görüş alınmıştır. Uzmanların görüşme sorularına ilişkin önerileri değerlendirilerek son hali verilmiştir.

Görüşme formunda bazı soruların (dört soru) alternatif sorusu ve sondaları bulunmaktadır. Akademisyenlerin zengin yaşam deneyimlerinin yakalanabilmesi için soruların anlaşılırlığı, işlerliği açısından ön uygulama iki ögretim elemanı ile gerçekleştirilmiş ve gerekli revizyonlar yapılmıştır. Bu veriler araştırmada analiz dışı bırakılmıştır.

\section{Araştırmanın Veri Toplama Süreci}

Araştırmanın veri toplama süreci Ekim 2017-Nisan 2018 tarihleri arasında 7 aylık süreçte gerçekleştirilmiştir. İkinci araştırmacı tarafından hemşire akademisyenler ile fakültede boş bir odada, yüzyüze ve hemşire akademisyenin mahremiyetine özen gösterilerek yarı yapılandırılmış sorulardan oluşan görüşme formu eşliğinde derinlemesine görüşmeler gerçekleştirilmiştir.

Hemşire akademisyenlerin deneyimleri ve kişisel özelliklerindeki farklılıklar nedeniyle görüşme süresinde farklılıklar oluşmuştur. Araştırmacının öngördüğü görüşme süresi 30-35 dakikadır. En kısa süren görüşme 13 dakika 20 saniye ve en uzun görüşme 42 dakika 42 saniye sürmüştür. Her görüşme sonrası veriler Word metni haline dönüştürülmüş ve analize hazırlanmıştır. Her görüşme metni için kod ve kategoriler tanımlanarak araştırmanın analiz süreci devam etmiştir. Veri toplama ve kodlama sürecini içeren veri çözümlemeleri eş zamanlı gerçekleştirilen süreçler olmuştur. Ses kayıt cihazına kaydedilen görüşmelerin Word metnine dönüştürülmesi ve kod ve temaların tanımlanarak oluşturulması süreci Ekim 2019 tarihinde tamamlanmıştır. Araştırmanın raporlanması Kasım 2019Ocak 2020 tarihleri arasında gerçekleşmiştir.

\section{Verilerin Değerlendirilmesi}

Görüşmeler tamamlandıktan sonra 24 saat içinde ses kayıtları dinlenip ham veriler 
bilgisayara aktarılmış ve bu veriler Microsoft Word belgesine dönüştürülmüştür. Görüşme metinleri oluşturulurken kaydedilmiş görüşmeler, titizce dinlenmiştir. Deşifre ederken hataları önlemek ve doğruluğu arttırmak için üç araştırmacı da kaydedilmiş görüşmeleri dinlemiş ve Word metinlerini okumuştur. Ön okuma sonrası yazılan Word metinleri analize hazır hale getirilmek üzere, 1-17 arasında sıralanmıştır (katılımcı numaraları şeklinde). Tematik analizde hem kelimeler hem de ifadeler hem de spesifik deneyimlerden oluşan önemli tanımlamalar üzerinde durulmuştur. Birbirine benzeyen verileri belirli kavram ve temalar çerçevesinde biraraya getirmek ve yorumlamak üzere yapılan tematik analiz süreci; ön okuma, nitel verilerin kodlanmas1, temalara ulaşma, veriyi örgütleme, yorumlama ve raporlaştırma şeklinde yapılmıştır. Hemşireliğin teorik, uygulama ve araştırma üçgeninde bir sağlı disiplini olarak tanımlanması, tema etiketi oluşturmada yol gösterici olmuştur. Veriler MAXQDA Analytics Pro programında analiz edilmiştir. Verilerin sunumunda ayrıntılı alıntılar ve atıf sayıları (f simgesi ile) gösterilmiştir. Atıf sayıları ile kastedilen görüşme metinlerinde kodların tekrar sayısıdır. Alıntılarda katılımcilara ait özellikler yanında katılımcı (K harfi ile) numarası ile birlikte (K5 gibi) gösterilmiştir.

\section{Araştırmanın Etik Yönü}

$\begin{aligned} & \text { Araştırma Helsinki Deklerasyonu } \\ & \text { olarak }\end{aligned}$
Prensipleri'ne
gerçekleştirilmiştir. X Uygun Üniversitesi Tıp
Fakültesi Sağlı Bilimleri Etik Kurulu'ndan
etik kurul onayı (Tarih: 27.09.2017, No:
20.478.486) ve X Üniversitesi Sağlı
Bilimleri Fakültesi Dekanlığı'ndan kurum
onayı (Tarih: 04.10.2017) alınmıştır. Hemşire

akademisyenlerden ses kayıt cihazı açıldıktan sonra sözlü onamlarının kaydı alınarak görüşmeye başlanmıştır. Bununla birlikte hemşire akademisyenlerden "Bilgilendirilmiş Gönüllü Olur Formu" ile çalışmaya katılma onayları yazılı olarak da alınmıştır.

\section{Araştırmada Geçerlik ve Güven Duyulabilirlik}

Araştırmada geçerliliği sağlamak için; araştırma sonuçları alıntılar ile beraber verilmiştir. Bulguların iç tutarlılık ve dış tutarlılık ölçütleri dikkate alınarak anlamlı bir bütün olup olmadığı üç araştırmacı tarafindan incelenmiştir. Tekrarlayıcı kelimelerin frekansı (sayısı) verilmiştir. Bulgular ayrıntılı sunulmuş ve tartışma kısmında alanyazın ile desteklenmiştir.

Çalışma ekibi üç düzey hemşire eğitimcisini (bir asistan, bir doktor öğretim üyesi ve bir doçent) içermektedir. Araştırmacıların hepsi nitel veri analizi konusunda sertifikaya sahiptir. Bir araştırmacı veri toplama sürecinde ve tüm yazarlar veri analizleri üzerinde çalışmıştır. Görüşme metinlerini ön okumada iki kodlayıcı (araştırmacı) ayrı ayrı kodlamış ve kodlama tutarlılığ 1 temelinde tek bir kod listesi oluşturulmuştur. Bununla birlikte, araştırma süreci basamakları ayrıntılı olarak yöntem kısmında açıklanmıştır. Ortaya çıkan temalar incelenen olgunun özünü toplu olarak açıklaması noktasında, güvenilirliği sağlamak noktasında ulaşılan temalar için katılımcı teyidi prosedürüne tabi tutulmuştur (4 öğretim elemanından katılımcı dönütü alınmıştır). Yazarlar görüşmelerde ve veri analizinde dürüstlük, doğruluk ve kendini kanıtlama konularını vurgulamışlardır. ${ }^{25}$ Çalışma raporunda COREQ kontrol listesi kullanılmıştır. ${ }^{2}$

\section{BULGULAR VE TARTIŞMA}

Araştırma grubunu oluşturan hemşire akademisyenlerin (n:17) hemşirelik öğrencileri hakkında deneyim ve beklentilerine yönelik görüşmelerden dört tema oluşturulmuş ve bu temalar ve atıf sayıları Şekil 1'de sunulmuştur. En çok atıf alan ve hemşire akademisyenlerin tümünün dile getirdiği (n:17) Zor Öğrenci (f: 558) teması olmuştur. Diğerleri ise; Hemşirelik Eğitiminde Engelleyici Faktörler (f: 109), Y Kuşağına Uygun Rol Model Hoca (f: 192) ve Sorgulayan Öğrenci (f: 16) 
şeklindedir. Hemşire akademisyenlerin $\mathrm{Y}$ kuşağ1 hemşirelik öğrencileri hakkında deneyim ve algılarına yönelik ulaşılan kavramsal modelde; ulaşılan iki tema var olan durumu betimlerken; diğer iki tema talep edileni tanımlamaktadır.

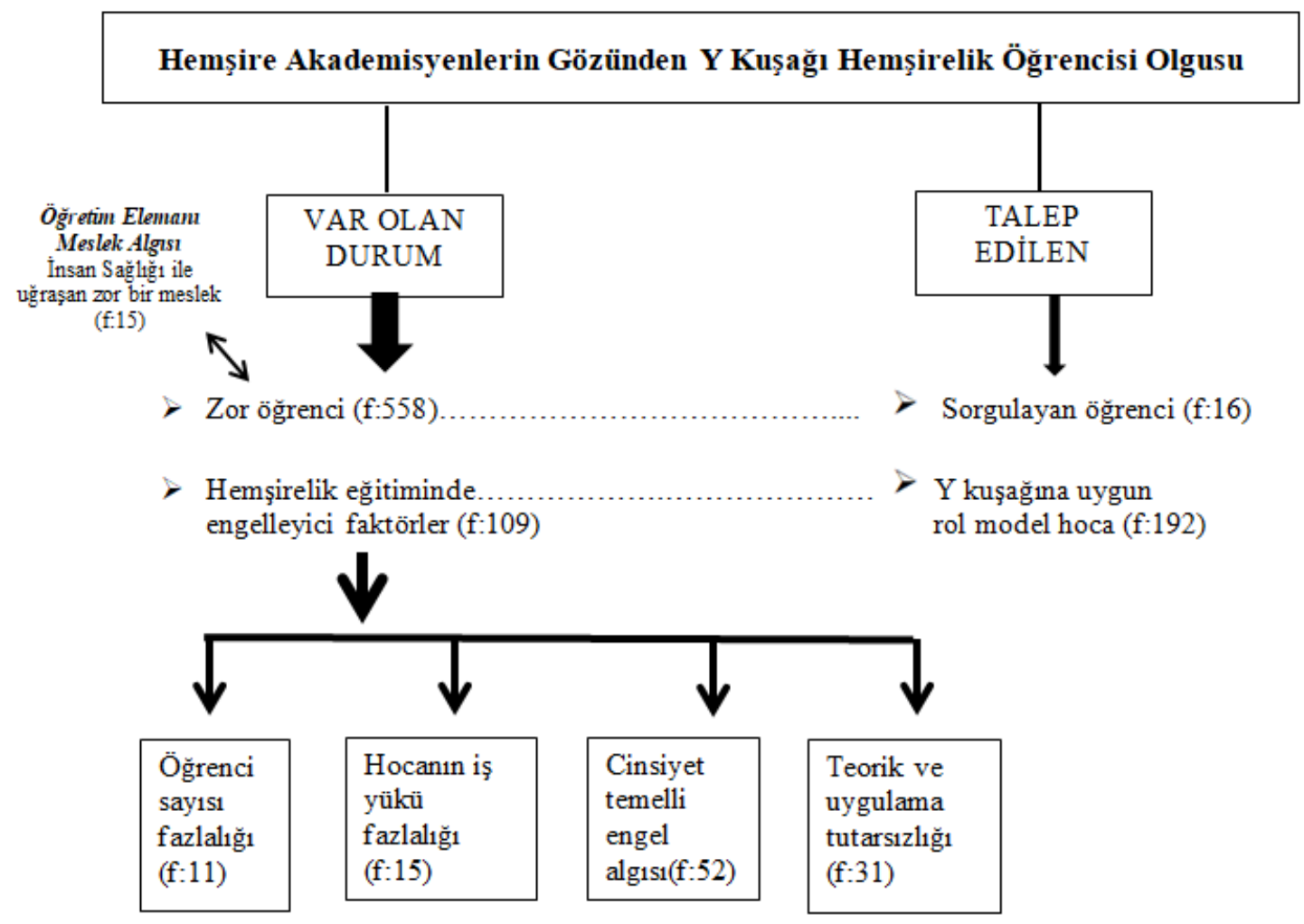

\section{Şekil 1. Hemşire Akademisyenlerin Y Kuşağı Hemşirelik Öğrencileri Hakkında Deneyim ve Algılarına Yönelik Ulaşılan Temalar ve Atıf Sayıları}

Y kuşağı hemşirelik öğrencileri hakkında deneyim ve algılarına yönelik olarak bu öğrencilerin zor olduğu algısı ve hemşirelik eğitimini engelleyici faktörlerin de eşlik ettiği tanımlanmış ve var olan durumu betimlemede kullanılan tema etiketleri olarak belirlenmiştir. $\mathrm{Bu}$ durumda hemşire akademisyenlerin alg1 ve beklentisi; sorgulayan öğrenci olması ve Y kuşağına uygun rol model hoca gerekliliği şeklinde etiketlendirilmiş temalardır.

\section{Tema 1: Zor Öğrenci}

"Zor Öğrenci" teması altında hemşire akademisyenler, Y kuşağı öğrenciler için isteksiz, ilgisiz, ders çalışmayan, internet odaklı gibi kelimeler yanında en çok zor kelimesini kullanmışlar ve in-vivo kodlama yapılarak bu temaya Zor Öğrenci etiketi verilmiştir. Hemşirelik 3. sınıflara ders veren katılımc1 13'e ait konuyla ilgili ifadeler aşağıda sunulmuştur:

"Y kuşağı öğrencileri zor bizim açımızdan $\mathrm{X}$ kuşağı olarak zor anlamaya çalışıyorum ama anladığımı da düşünüyorum ancak çok da Y kuşağı stratejilerini geliştirebildiğimi sanmiyorum daha o konuda eksiklerim olduğunu düşünüyorum çünkü hep X kuşağı gibi X kuşağı anlayışıyla yaklaştığım için bizim için çalışmak değerli bizim için insan değerli işte süreklilikle bir şeyi yapabiliyoruz para olmasa da olur noktasina da gelebiliyoruz ama Y kuşağı tam tersi olduğu için Y de bunlar değişiyor öyle olunca bocaladığımı hissediyorum gerçekten ne yapacağımı bilemiyorum gerçekten netleşmiş değilim $Y$ kuşağı ile ilgili aynı dili konuştuğumuzu sanmiyorum..." K13, 45 yaş, Doçent, 23 yıl deneyim 
Hemşire akademisyenlerden 3 . ve 4 . sınıfların ders ve uygulamalarını yürüten ikisi öğrencilerin Zor Öğrenci teması altında isteksiz ve ilgisiz olmalarını şöyle ifade etmişlerdir:

"Öğrencilerle ilgili bir de tabi şunu söyleyebilirim sürekli birilerinin onları bir şeylere sürüklemesini bekliyorlar. Kendilerinin bir şeyi yapmak gibi bir istek içerisinde olmuyorlar isteksizlikleri oluyor, bu konuda biraz sıkıntı duyuyorum ben açıkçası. Sanki hep bir şeyi söylemek zorundayız ite kaka birilerinin dürtmesi gerekiyor gibi bir durum söz konusu oluyor." K17, 39 yaş, Dr. Öğr. Üyesi, 14 yıl deneyim

"Şimdi günümüzde ki hemşirelik öğrencilerinin beklentilerinin farklı olduğunu düşünüyorum çünkü bizler ders anlatırken ya da hocalarımız ders anlatırken çok dinlemiyorlar dinlemek istemiyorlar yani gelen öğrenciler biraz daha isteksiz ilgisiz. İçlerinden ilgili olanlar az... hemşirelik öğrencilerini şöyle değerlendiriyorum daha çok garanti bir meslek olarak bakıldığı için işte garanti bir meslek atama kriterleri biraz daha kolay görüldüğü için maaş almak amaçlı girilen bir meslek olarak görüyorum yada aile zorunluluğu ile gelenler var. Kendi isteğiyle gelen grubun daha az olduğunu düşünüyorum. Zaten kendi isteğiyle gelen grupta derslerde kendini fark ettiriyor derse daha aktif katılıyorlar uygulama alanlarında da daha başarılılar.” K8, 27 yaş, Araştırma görevlisi, 4 y1l deneyim

Araştırma görevlisi hemşire akademisyen öğrencilerin internet odaklı olmalarına ilişkin şu ifadeleri kullanmıştır:

"Hemşirelik öğrencileri yani yeni nesil olarak baktığımızda bu y kuşağında tabi ki süreç ilerledikçe öğrencilerinde bilgi edinme yolları değişiyor. Daha fazla internet odaklı, daha fazla araştırma konusunda kısıtlı kaynaklara kendilerini verip doğru olmayan farklı bilgilerle daha hızlı bir şekilde elde edinme, bilgi edinmeye çalışabiliyorlar, bu biraz sıkıntılı bir süreç olabiliyor ama bunun yanı sıra tam tersi olan araştırmaya daha çok meyilli olan öğrencilerde teknolojinin getirmiş olduğu yeni olanakları kullanarak çok daha farklı gelişim yolları izleyebiliyorlar." K10, 32 yaş, Araştırma görevlisi, 6 yıl deneyim

\section{Tema 2: Hemşirelik Eğitiminde Engelleyici Faktörler}

Akademisyen hemşireler var olan durumu betimlemede Hemşirelik Eğitiminde Engelleyici Faktörler teması altında cinsiyet temelli engel alg1s1, teorik ve uygulama tutarsızlığı, öğrenci sayısınınn fazlalığı ve hocanın iş yükü fazlalığ 1 ifadelerini sıklıkla belirtmişlerdir. $\mathrm{Bu}$ tema altında 1., 2. ve 3 . sinıflarda ders veren katılımcilara ait cinsiyet temelli engel algısı ile ilgili alıntılar aşağıda sunulmuştur:

“...erkek öğrenciler ile k1z öğrenciler kıyaslandığında k1z öğrencileri erkek öğrencilerden daha başarılı buluyorum bunu nerden çıkarıyorum not ortalamalarına göre söylüyorum uygulamalarına göre söylüyorum ve laboratuvardaki becerisine göre söylüyorum isteklilikte o yönde erkek öğrencilerinin az bir topluluk olduğu için erkek öğrencilerin daha çok tercih yönü mesleği tercih etme yönünü soruyorum sorularına göre cevap veriyorum ... Erkeklerde beceri daha iyi geliyor bana manipülasyonları daha iyi geliyor kızlara göre fakat teorileri çok iyi değil 2 yıldır fakülte olduktan sonra erkek öğrencilerin profillerini çok iyi buluyorum artış var. Düzelme var.” K2, 38 yaş, Dr. Öğr. Üyesi, 12 yil deneyim

"...herhalde en büyük sorun mesela iletişim. $\mathrm{Bu}$ arada bu iletişimi öğrenciye vermek gerekiyor. Özellikle erkek öğrencilerde daha fazla iletişim sorunu görüyorum hastaya yaklaşmakta çekiniyorlar, kız öğrenciler bu konuda biraz daha asertif erkekler bu konuda biraz daha çekingen kalıyor." K7, 56 yaş, Profesör, 24 y1l deneyim

"Kızlar daha sorumluluk sahibiydi. Şimdi benzer olmaya başladılar böyle itaat eden değil her dediğini yapan anlamında söylemiyorum; daha dinler daha çaba gösterir verdiğin sorumluluğu yerine getirir noktasındaydı. Ama azaldı yine var tabii kız 
öğrenciler bu anlamda daha sorumluluk sahibi, ne kadar inkar etsekte cinsiyetin bazı şeylere etkileri oluyor doğal olarak oluyor yani hemşireliğin bakımla ilgili olan kısmında kızlar doğal olarak daha yatkın olabiliyorlar erkekler daha teknik daha net olabiliyorlar bazı mesela erkek öğrencilerde bilgisine vesairesine bayağ 1 bir çaba gösterip sahip oluyorlar net bir şekilde ortaya koyabiliyorlar da o da var bu da ilginç bir şekilde karşımıza çıkabiliyor..." K13, 45 yaş, Doçent, 23 yıl deneyim

\section{Hemşirelik eğitiminde engelleyici} faktörler teması altında yer alan teorik ve uygulama tutarsızlı̆̆ ile ilgili katılımcı 5 Dr. Öğr. Üyesinin ifadeleri şöyledir:

"Hep böyle kanıta dayalı uygulamalardan ya da bilimsel sonuçlara dayalı teorik bilgilerden bahsediyoruz yani derslerde 6 saat 10 saat işte kitabi bilgi böyle demektedir bu kanıt düzeyindedir bir sürü şeyi söylüyoruz ama birçok kliniğe gittiğimizde o kanıta dayalı uygulama diye anlattığımız teoride duvarlar arkasında anlattığınız şeyleri belki klinik uygulamasını o şekilde yapamıoruz bu yine bizim elimizde olan bir şey değil çünkü kliniğinde bir işleyişi var hani şunu demekten hep yüreğim sızlamıştır arkadaşlar bu derste böyle ama klinikte böyle uygulayacağız hani bunun neden mesela neden işte nesilden bahsediyorsun ya neden diye sorduklarında bunun yanitı yok ..." K5, 36 yaş, Dr. Öğr. Üyesi, 10 yıl deneyim

\section{Hemşirelik eğitiminde engelleyici} faktörler teması altında yer alan öğrenci sayısının ve hocanın iş yükü fazlalığ konularında bazı katılımcıların ifadeleri şunlardır:

"Öğrenci sayısının fazla olması nitelikli ve kaliteli eğitim sürecinin devam etmesini azalttı çünkü eskiden 30 tane öğrenci ile birebir hepsinin sorunlarını vesaire daha bire birdik ama şimdi sınıflar böyle 200300 lere varınca böyle açıkçası her öğrenciye maalesef ulaşamıyoruz her öğrenciyle de birebir interaktif şeyimiz olmuyor böyle bir sıkıntısı var bu sistem kaynaklı da bir sıkıntı öyle olunca nicel olarak sayı artıyor ama nitel olarak kalite anlamında yeni nesil böyle bir mezun vermek zorunda kalıyoruz çünkü bir bakıyorsunuz öğrenci birçok uygulamayı yapmadan uygulamanın getirdiği yerden kaynaklı uygulama yapamadan mezun oluyor.” K17, 39 yaş, Dr. Öğr. Üyesi, 14 yıl deneyim

"İş yükümüzün de diğer alanlara göre daha fazla olduğunu düşünüyorum. Çünkü bir önceki soruda tanımladığım gibi öğrencileri yetiştirmek olması gerekiyor amacımız hem doğru iletişim tekniklerine hem teorik bilgiyi hem pratiği öğretmek son derece güç ve sorumluluk sahibi olduğumuzu düşünüyorum.” K 12, 45 yaş, Dr. Öğr. Üyesi, 17 y1l deneyim

"Mesela benim olumsuz olarak gördüğüm kısım bir mesai kavramının olmaması hemşireler nöbet listesine göre çalışıyorlar. Mesaiden çıktıktan sonra zaman tamamen kendilerine ait ama biz akademisyen olarak böyle bir lükse sahip değiliz yani okulda çalıştı̆̆ımız gibi işlerimizi hem okul hem eve götürmek zorunda kalıyoruz. Yeri geliyor hafta sonu yeri geliyor bayramlarda herkesin tatil yaptığı zamanlarda bile bizim çalışmamı gerekiyor aynı zamanda hastanede çalışan hemşirelerde farklı olarak sürekli hazır olmamız gereken derslerimiz sinavlarımız oluyor.. rutin monoton bir döneme girmiyor yani mesleğimiz onun dışında lisede çalışan öğretmenlere göre sağl1k meslek lisesi öğretmenlerine göre üniversite öğrencilerinin beklentilerini karşılamak açısından da çok çalışıp emek vermek güncel kalabilmek gerekiyor $\mathrm{o}$ yüzden de daha çok çaba harcamak açısından daha zor." K3, 28 yaş, Araştırma görevlisi, 6 y1l deneyim

\section{Tema 3: Y Kuşağına Uygun Rol Model Hoca}

Hemşire akademisyenlerin beklentileri; Sorgulayan Öğrenci ve buna uygun Y Kuşağına Uygun Rol Model Hoca şeklinde tanımlanmıştır. Y Kuşağına Uygun Rol Model Hoca teması altında hemşire akademisyenler; güncel bilgileri yenileyip kendini geliştiren, sorgulayan, konu anlatırken farklı örnekler veren, öğrencilere bağımsız hissedecekleri sorumluluklar veren 
ifadelerini ve rol model ifadesini yaygın olarak kullanmışlardır. İn-vivo kodlama ile katılımcı ifadesinden oluşturulmuş bu tema etiketi ile 1. sinıf hocalarından Katilımc1 2'nin ifadeleri aşağıda sunulmuştur:

“...Ayrıca bir süreç yani tek işimiz bizim ders anlatmak değil bakım öğretmek değil bence bu hayata hazırlamak insan olmayı da öğretmek gerekiyor bazı değerleri kazandırmak gerekiyor. Bunun için de rol model olmamız lazım şunu görüyorum öğrenciler evet bu konuda almaya açıklar farklı bir konudan bahsettiğiniz zaman sosyal ilişkilerle ilgili öğrencinin daha çok dikkatini çekiyor. Çünkü bunu hayatında kullanabileceğini düşünüyor. Dediğim gibi gelen öğrenciler farklı sosyo kültürel özelliklere sahip bunları anlamak ihtiyaçlarını bilmek ögretim üyesi olarak görevlerimiz diye düşünüyorum ihtiyaçlarına göre davranabilirsek...Buna cevap verebilirsek öğrenciyi daha iyi hayata ve mesleğe hazırlayabileceğimizi düşünüyorum.. Gelen öğrenci yalnızca bir meslek sahibi olarak gitmeyecek buradan yetişkin olmayı da öğrenecek topluma iyi bir birey olarak katılmış olacak donanımlı bir birey olarak katılmış olacak... Sifirdan gelen bir öğrenciye bu mesleği sevdirmek... Bu mesleğin ne olduğunu göstermek iyi bir rol model olmak da çok önemli..." K2, 38 yaş, Dr. Öğr. Üyesi, 12 yıl deneyim

Katılımcı 4, 6 ve 13'ün $\mathbf{Y}$ Kuşağına Uygun Rol Model Hoca temasi altında kategorize edilmiş ifadeleri de aşağıdadır.

“...teorik bilgi olarak yeterli olmak ayrıca güncel alanları da takip etmek gerekiyor ve o eğitim durumunuzun gerektirdiği aşamaları tamamlamamız da gerekiyor. Yani muaf olmamız gereken dersleri almanız lazım işte nedir yeterliliğe girip geçmiş olmanız lazım.. yani kendinizi bazı basamaklardan başarılı bir şekilde geliştirmeniz gerekiyor öyle söyleyeyim hepsini kapsıyor herhalde çünkü sadece öğretmenlik gibi değerlendirmemek lazım akademisyenlik daha farklı bir şey teorik olarak artı günceli takip etmek bir de bunları öğrencilere aktarabilmek gerekiyor yani birçok becerinin bir arada olması lazım.” K4, 30 yaş, Araştırma görevlisi, 5 yıl deneyim

"Daha çok çaba harcamak zorunda bırakıyor beni bir konuyu çok farklı örneklerle onun anlayabileceği onun dikkatini çekebileceği şekilde anlatmak zorunda kalıyorum. Çünkü $\mathrm{Y}$ kuşağı teknoloji biraz daha yakın bir kuşak bizim kuşak gibi değil slayttan anlatıp ben dersi asla geçemem ister cerrahi olsun ister etik olsun sürekli örnekler ve medyaya çıkan örnekler benim daha önceki deneyimlerim de karşılaştı̆gım örnekleri anlatarak onların dikkatini çektikten sonra teorik bilgi anlatabiliyorum...Yani önce onların ilgisini çeker hale getirmek gerekiyor" K6, 38 yaş, Dr. Öğr. Üyesi, 13 yıl deneyim

\section{Tema 4: Sorgulayan Öğrenci}

Hemşire akademisyenler Sorgulayan Öğrenci teması altında; araştırıcı ruha sahip, güncel bilgi ve yenilikleri takip eden, özgürlükçü kelimeleriyle birlikte en sik sorgulayan ifadesini kullanmışlardır. Dördüncü sınıf öğrencilerle ders ve uygulamaları yürüten Katılımcı 17'nin Sorgulayan Öğrenciye yönelik ifadeleri aşağıda sunulmuştur:

"İşte artı eksi var aslında olması gereken sorgulayan düşünen bir grubun olması iyi ama bunun da bir dozunun olması lazım bir sınırının olması lazım. Her böyle gardını alan her şeyi de yapmaması gerekiyor belli kuralları da çiğnememek gerekiyor özgürüm deyip de her dediğimi yapacağım anlamına gelmiyor. Tamam pasif değil itaat eden değil. Bunu asla istemiyoruz eski grup biraz daha böyleydi. Şimdikiler sorgulayan özgürlüklerine daha düşkün ama bunun da sınırlılıkların dahilinde yapılması mesafelerin konulması gerektiğini düşünüyorum her şeye muhalefet de iyi olmuyor bazen dezavantaja dönüşebiliyor...Bir kere önce bilgiyi araştıran daha çok birilerinin ona değil de onun böyle bilgiyi araştırmakla ilgili bir motivasyonunun olması kesinlikle gerekiyor. Güncel bilgileri takip eden yenilikleri takip eden kendisinin de yeniliklere açık olacağ birtakım özelliklerinin olması gerekiyor zaten bunları gerçekleştirirse hem kendini 
geliştirecektir hem de meslek adına bir takım şeyler yapacaktır diye düşünüyorum. ... şimdi çalışan bir grup var yine kliniklerde görüyoruz her söyleneni yapan usta çırak gibi şeyleri görüyoruz ama yeni nesilin özellikle bundan sonraki süreçte daha çok araştıran sorgulayan böyle bir şeyin düşünce ya da kişisel anlamda yaşantısı olması gerekiyor". K17, 39 yaş, Dr. Öğr. Üyesi, 14 yıl deneyim

Katılımc1 7, 12 ve 17 görüşmelerde Sorgulayan Öğrenci temasına yönelik sorgulayan bir öğrencide olması gereken özelliklerden bahsetmişlerdir.

“...sorgulayan araştıran beni de araştırmaya iten öğrenci benim anlattığımı moda mod ezberleyip sinavda bana bunu aynen geri veren değil bilgiyi sindirip onu yorumlamak kendinden bir şeyler katmak ya da o bilginin neden olduğunu sorgulamak.. yani bana kanit aratmak zorunda birakan öğrenci aa bunu nasıl oldu da düşünemedim diyebilmem gerekiyor.. Ben böyle istiyorum Benim için ideal öğrenci bu...” K7, 56 yaş, Profesör, 24 y1l deneyim

"Evet iyi bir gözlemci ve analitik beceriye sahip olması gerekiyor. İdeal bir hemşirelik öğrencisi insanı anlayabilmeli iletişimi iyi olmalı yardımsever olmalı analitik düşünme becerisine sahip olmalı hastalık durumunda neden sonuç ilişskisini iyi bilmeli ve $o$ doğrultuda hemşirelik bakımını planlayabilmeli yani zeka düzeyi daha yüksek olması gerekiyor analitik düşünme becerisine sahip olabilmesi için" K12, 45 yaş, Dr. Öğr. Üyesi, 17 yıl deneyim

"Vallahi ben en çok dediğim gibi eski grubun biraz daha pasif yeni grubu biraz daha hakkını arayan muhalefet dediğim yeni nesil biraz daha özgürlükçü daha böyle hani kendine bireysel olarak çok müdahale istemeyen bir grup gibi görüyorum ... İşte artı ve eksi yönleri var aslında olması gereken sorgulayan düşünen bir grubun olması iyi ama bunun da bir dozunun olması lazım bir sınırının olması lazım ... Şimdikiler sorgulayan özgürlüklerine daha düşkün Ama bunun da sinırlılikların dahilinde yapılması mesafelerin konulması gerektiğini düşünüyorum her şeye muhalefet de iyi olmuyor bazen dezavantajı dönüşebiliyor." K17, 39 yaş, Dr. Öğr. Üyesi, 14 yıl deneyim,

$\mathrm{Bu}$ araştırmada hemşire akademisyenlerin Y kuşağ 1 hemşirelik öğrencileri hakkında deneyim ve algıları nitel görüşmeler ile betimlenmeye çalışılmıştır. Hemşirelik öğrencilerinin zor olduğu alg1s1 ve $Y$ kuşağına özel olmasa da hemşirelik eğitimini engelleyici faktörler var olan durumu betimlemede kullanılırken; sorgulayan öğrenci ve $Y$ kuşağına uygun rol model hoca var olan bu durumda hemşire akademisyenlerin beklentisi olarak etiketlenmiş temalardır.

$\begin{array}{cccc}\begin{array}{c}\text { Toplumsal } \\ \text { dönüşümler }\end{array} \text { öğrenci } & \begin{array}{c}\text { değişim } \\ \text { profilini }\end{array} & \text { ve } \\ & \text { de }\end{array}$
değiştirmekte, öğrencilerin sahip olmaları gereken becerileri artırmakta ve öğrencilere sunulacak eğitimin özelliklerini de değiştirmektedir. Son yıllarda ekonomistler tarafından ortaya atılan; ancak eğitimcilerin de dikkat etmeleri gereken konu ise eğitimin hedef kitlesini oluşturan kuşaklardır. Karakterleri, çalışma ve sosyal yaşamları bakımlarından kuşaklar arasında önemli ayrışmalar bulunmaktadır. Y Kuşağının bağımsız olmayı sevdiği, özgürlüklerine düşkün ve iş ve eğitim yaşamlarında farklı olduğu, dolayısıyla bu kuşağı işin bir parçası durumuna getirmenin oldukça zor olduğu ifade edilmektedir. Bununla birlikte Y kuşağının aşırı bireyci ve otorite tanımama özelliği dolayısıyla uyumsuz ve kendisinden farklı düşünenleri acımasızca eleştiren bireyler olduğu da belirtilmektedir. ${ }^{27}$

$\mathrm{Bu}$ çalışmada "Zor Öğrenci” teması altında eğitmenlerin öğrencilere yönelik ifadelerine bakıldığında $\mathrm{Y}$ kuşağı öğrenciler için isteksiz, ilgisiz, ders çalışmayan, internet odaklı gibi kelimeler yanında en çok zor kelimesini kullanmışlardır. $\mathrm{Bu}$ çalışma bulgularına benzer olarak bir çalışmada $\mathrm{X}$ kuşağ1 akademisyenlerin $\mathrm{Y}$ kuşağ öğrencilerin özellikleri ile ilgili genel olarak olumsuz bir algıya sahip olduğu ve öğrencilerin öğrenme kabiliyetlerinin yetersiz olduğunu belirtmişlerdir. ${ }^{5}$ Nitel bir çalışmada sosyal bilgiler alanında akademisyenlerin görüşleri incelenmiş, öğrencilerin bölümü 
severek ve isteyerek gelmemesinin ögrencilerde motivasyon kaybı ve derse olan ilgisizliğe yol açtığı saptanmıştır. ${ }^{20}$ Erzurum'da bir çalışmada öğretim elemanları öğrencilerin alan ile ilgili kendilerine verilen kaynaklardan başka kaynaklara başvurmadığı, alan dışı yayınları takip etmediği, derslere hazırlıksız geldiğini belirtmişlerdir. ${ }^{19}$ Yurtdışında çalışmalarda da benzer bulgular elde edilmiş, Güney Afrika'da hemşire eğitimciler öğrencilerden sayg1, dakiklik, dürüstlük ve dersleri aktif olarak dinlemelerini beklemektedir. ${ }^{7}$ İngiltere'de hemşirelik öğrencilerinden beklenilen bilişsel özellik dürüstlük ve bilgi birikimi, klinik uygulamada bilgisi olmadığ uygulamaları yapmama, titizlik ve hassasiyet olarak belirlenmiştir. ${ }^{11}$ Amerika'da öğrencinin iletişim probleminin ilk sırada yer aldığı; daha sonra öğrencinin ilerleme kaydedemediği, hatalı ilaç uygulama, hasta bakımına öncelik verememe, derslere hazırlıksız gelme, sınıfın gerisinde olma, anksiyeteli olma, kendine güvenmeme ve profesyonel olmamanın başarısız öğrencilerde en temel özellikler olduğu vurgulanmıştır. ${ }^{9}$ Diğer bir çalışmada Amerika'da hemşire eğitimciler başarısız öğrencileri klinik uygulamalara hazır olmayan, klinik alanda çalışmayan, güvensiz, yasal-etik ilkeleri ihlal eden ve iletişim becerilerinde zorluk çeken öğrenciler olarak tanımlamışlardır. ${ }^{8}$ Çalışma sonuçlarından görüldüğü gibi eğitimciler öğrencilerden derse ilgili olmalarını, araştırmacı ve sorgulayıcı olmalarını beklemektedir.

Akademisyen hemşireler var olan durumu betimlemede cinsiyet temelli engel algisı, teorik ve uygulama tutarsızlığı, öğrenci sayısınınn fazlalığı ve hocanın iş yükü fazlalığı işaret eden ifadeleri kullanmışlar ve bu ifadeler Y kuşağına özel olmayıp genel hemşirelik eğitimini kapsadığı için "Hemşirelik Eğitiminde Engelleyici Faktörler" tema etiketi ile isimlendirilmiştir. Farklı çalışmaları içeren alanyazında çalışma bulgularına benzer şekilde klinik uygulama alanların yetersizliği ve okul ile klinik alan arasında iş birliğinin eksik olması, teorik ve klinik alan arasında bir boşluğun olması ve öğrenci sayısının fazlalığı dolayısı ile eğitimcinin iş yükünün fazlalığının hemşirelik eğitiminde belirtilen sorunların başında yer aldığı belirtilmektedir. ${ }^{28-31} \mathrm{Bu}$ faktörler her ne kadar araştırmada araştırılan olguya dair özel olmasa da; atıf sayısı göz önüne alındığında $Y$ kuşağı öğrencilerin algısında da etkili bulunmuştur. Belki de sadece bu kuşağa özel değilse de; Y kuşağında zor öğrenciyi besleyen perde arkası faktörler olarak değerlendirilebilinir.

Hemşire akademisyenler güncel bilgileri yenileyip kendini geliştiren, sorgulayan, konu anlatırken farklı örnekler veren, öğrencilere bağımsı hissedecekleri sorumluluklar veren ve rol model ifadelerini sıklıkla dile getirmişlerdir, kodlamada bu ifadeler "Y Kuşağına Uygun Rol Model Hoca" teması altında kategorize edilmiştir. Bilindiği gibi hemşire eğiticilerinin alanında yetkin olması hemşirelik eğitiminin kalitesini önemli derecede etkilemektedir. ${ }^{32}$ Öğrencilerin eğitimcilerden beklediği araştırmalar incelendiğinde öğrenciler eğitimci ders anlatırken konuya hakim olmasının ve ses tonu, konuşması ve diksiyonunun etkili olmasının önemli olduğunu belirtmişlerdir. ${ }^{13,16,29}$ Bununla birlikte, akademisyenlerin öğrencilere çalışma yaşantılarında kullanabilecekleri bilgileri kazandırmaya çalışmasının ve derslerin araştırmaya yönlendirici olmasın 12 , öğrencilerin derste aktif rol almak istedikleri $^{16}$, öğrencilerin sinıfta kendini ifade edebilmelerine ve derse katılmalarına imkan sağlayacak bir ortam oluşturması da belirtilmiştir. ${ }^{13,16,29}$ Benzer olarak İran'da yürütülen nitel bir çalışmada ulaşılan temalardan birisi öğrencinin öğrenmesinde eğitmenin bilgi, motivasyonu ve uzmanlaşmış eğitimlere sahip olmasının önemli olduğu tanımlanmıştır. ${ }^{33}$ Alan yazında çalışma sonuçlarında ve bu araştırma bulgularında, hemşire akademisyenler kendilerinde olması gereken özellikleri $\mathbf{Y}$ Kuşağına Uygun Rol Model Hoca teması altında benzer ifadeler ile vurgulamışlardır.

Hemşire akademisyenler "Sorgulayan Öğrenci” teması etiketi altında öğrenciler 
için istenilen/talep edileni araştırıcı ruha sahip, güncel bilgi ve yenilikleri takip eden, özgürlükçü kelimeleriyle birlikte, sıklıkla sorgulayan ifadesini kullanarak betimlemişlerdir. Bilindiği gibi son yıllarda eğitimin amacının ezberci kuşaklar yetiştirmek olmamas1, sorgulayan nesiller yetiştirebilmenin önemi ve öğrencilerde kritik düşünme becerilerini geliştirmesi önemle vurgulanmaktadır. ${ }^{34,35} \mathrm{Bu}$ konuda yeni anlayışlar oluşturma ve gerçekleştirmede

hem

hemşirelik eğitmenlerine hem de öğrencilere büyük sorumluluklar getirdiği belirtilmiştir. ${ }^{35}$ Öğrencilerde merak uyandırma, eleştirel ve yansitıcı düşünmeyi geliştirme, ögrendiklerini uygulamaya aktarmada sorgulama etkinliklerinin büyük payı bulunmaktadır. ${ }^{36}$ Çalışma bulgusu da alanyazını destekler nitelikte öne çıkmaktadır.

\section{SONUÇ VE ÖNERİLER}

Çalışmada hemşire akademisyenlerin Y kuşağı hemşirelik öğrencileri için deneyim ve algıları var olan durum ve talep edilen şeklinde iki başlıkta ele alınmıştır. Var olan durumu zor öğrenci algısı ve bu kuşağa özel değilse de; Y kuşağında zor öğrenciyi besleyen perde arkası faktörler olarak değerlendirilebilecek hemşirelik eğitiminde engelleyici faktörler temaları tanımlarken; sorgulayan öğrenci ve Y kuşağına uygun rol model hoca hemşire akademisyenlerin beklentisi olarak talep edileni betimlemektedir. Farklı kültürlerde yürütülen çalışmalar ve bu araştırmanın sonuçları doğrultusunda, hemşire eğitimcilerin deneyim ve algılarının benzer olduğu söylenebilir. Hemşire eğitimcilerin bakış açısıyla öğrencilerin sahip olması gereken özelliklerin bilinmesi, öğrencilerin de kendini geliştirmesi ve nasıl algılandığının farkına varılması açısından oldukça önemlidir. Çünkü hemşirelik eğitiminin kalitesi değerlendirilirken hemşirelik öğrencilerinin eğitimciden beklediği özelliklerin incelenmesi ya da öğrencilerin sorunlarının ve isteklerinin belirlenmesi eğitimde kaliteyi ileriye taşıyabilmek açısından zorunlu ve gerekli olsa da, eğitimciler gözüyle öğrencilerinde değerlendirilmesi eğitim kalitesinde yaşanan öğrenci odaklı sorunların belirlenmesi açısından son derece önemlidir.

Sonuçta bu çalışmada hemşire eğitimciler, öğrencilerin kuşak özellikleri ile benzer olan zorluğu dile getirmeleri yanında, kendileri ile ilgili Y kuşağına uygun rol model eğitimci tanımlaması ile var olan durumla baş etmede yol gösterici yaklaşımları sunmaları araştırma konusuna 1 şı tutar niteliktedir. Kuşaklar arası değişimler ve her kuşağın özelliklerinin farklılaştığı göz önüne alındığında bu değerlendirmelerin öğrenciler ve eğitimciler açısından belirlenmesinin alan yazına katkı sağlayacağı düşünülmektedir.

\section{KAYNAKLAR}

1. Adıgüzel, O, Batur, H. ve Ekşil, N. (2014). "Kuşakların Değişen Yüzü ve Y Kuşağı İle Ortaya Çıkan Yeni Çalışma Tarzı: Mobil Yakalılar". Süleyman Demirel Üniversitesi Sosyal Bilimler Enstitüsü Dergisi, 1 (19), 165-82.

2. Sevinç, E. ve Kavgaoğlu, D. (2019). "Kuşakların Hemşirelikte Yönetim ve Eğitim Pratikleri Açısından İncelenmesi”. İstanbul Gelişim Üniversitesi Sağllk Bilimleri Dergisi, 9, 944-957.

3. Altuntuğ, N. (2012). "Kuşaktan Kuşağa Tüketim Olgusu ve Geleceğin Tüketici Profili”. Organizasyon ve Yönetim Bilimleri Dergisi, 4 (1), 203-212.

4. Yüksekbilgili, Z. (2013). "Türk Tipi Y Kuşağı”. Elektronik Sosyal Bilimler Dergisi, 12 (45), 342-353.

5. Mücevher, M.H. (2015). $X$ ve $Y$ Kuşağının Birbirlerine Karşı Özellik ve Etkileşim Algıları: SDÜ Örneği. Yüksek Lisans Tezi, Süleyman Demirel Üniversitesi Sosyal Bilimler Enstitüsü, Isparta.
6. Uğurlu, T.Y. (2013) "Öğretmenlerin İletişim Becerisi ve Empatik Eğilim Davranışlarının Çocuk Sevme Düzeyleri Üzerine Etkisi”. Pegem Eğitim ve Öğretim Dergisi, 3 (2), 51-61.

7. Mathevula, F.R. and Khoza, L.B. (2013). "Nurse Educators and Student Nurse Neophytes' Perceptions of Good Interaction in the Classroom Setting". Health SA Gesondheid, 18 (1), 1-9.

8. Lewallen, L.P. and DeBrew, J.K. (2012). "Successful and Unsuccessful Clinical Nursing Students". Journal of Nursing Education, 51 (7), 389-395.

9. DeBrew, J.K. and Lewallen, L.P. (2014). "To Pass or to Fail? Understanding The Factors Considered by Faculty in The Clinical Evaluation of Nursing Students". Nurse Education Today, 34 (4), 631-636. 
10. Killam, L.A, Luhanga, F. and Bakker, D. (2011). "Characteristics of Unsafe Undergraduate Nursing Students in Clinical Practice: an Integrative Literature Review". Journal of Nursing Education, 50 (8), 437-446.

11. Monique, K, Elizabeth, A, Lise, O. and Lisa, M. (2019). "Unsafe Student Nurse Behaviours: The Perspectives of Expert Clinical Nurse Educators". Nurse Education in Practice, 41:102628. https://doi.org/10.1016/j.nepr.2019. 102628.

12. Cimete, G. (1998). "Öğrenci-Öğretim Elemanı Etkileşimine Yönelik Kalitatif Bir Çalışma”. Cumhuriyet Üniversitesi Hemşirelik Yüksekokulu Dergisi, 2 (1), 9-19.

13. Yanıkkerem, E. ve Aycan, N, Kitapçıŏlu, G, Korkmaz, A, Çalık, C. (2006). "Öğrencilerin Hemşire Eğitimcilerde Aradığ Özelliklerin Değerlendirme Aracının Geliştirilmesi Çalışması". Ege Üniversitesi Hemşirelik Yüksekokulu Dergisi, 22 (1), 37-53.

14. Çelikkalp, Ü, Aydın, A. ve Temel, M. (2010). "Bir Sağlık Yüksekokulu Hemşirelik Bölümü Öğrencilerinin Aldıkları Eğitime İlişkin Görüşleri”. Maltepe Üniversitesi Hemşirelik Bilim ve Sanatı Dergisi, 3 (2), 3-14.

15. Günüşen, N.P. ve Üstün, B. (2012). "Hemşirelik Öğrencilerinin Klinik Eğitimde Verilen Geribildirime Yönelik Görüşleri". Journal of Anatolia Nursing and Health Sciences, 15 (3), 197-204.

16. Atasoy, I. ve Sütütemiz, N. (2014). "Bir Grup Hemşirelik Son Sinıf Öğrencisinin Hemşirelik Eğitimi İle İlgili Görüşleri”. Florence Nightingale Hemşirelik Dergisi, 22 (2), 94-104.

17. Nazik, E. ve Arslan, S. (2014). "Hemşirelik Mesleğinin Geleceği: Öğrencilerin Beklentileri”. Bozok Tıp Dergisi, 4 (1), 33-40.

18. Akbaş, M. ve Sürücü, Ş.G. (2019). “Öğrenci Hemşirelerin Klinik, Sınıf ve Ders Dışı Ortamda Öğretim Elemanlarından Beklentileri”. Mersin Üniversitesi Tıp Fakültesi Lokman Hekim Tip Tarihi ve Folklorik Tip Dergisi, 9 (1), 45-54.

19. Kaya, H.İ, Bay, E. ve Şebin, K. (2007). “Öğretim Elemanlarının Ders Verdikleri Öğrencilerin Özelliklerine İlişkin Görüşleri”. Atatürk Üniversitesi Sosyal Bilimler Enstitüsü Dergisi, 10 (2), 221-231.

20. Yılmaz, K. (2010). " Sosyal Bilgiler Eğitimindeki Sorunlar ve Çözüm Önerileri: Öğretim Elemanlarının Görüşleri”. Türk Eğitim Bilimleri Dergisi, 8 (4), 839-867.

21. Soba, M. (2012). "Üniversite Öğrencilerinin Performanslarının Akademisyenler Tarafından Analitik Hiyerarşi Süreci İle Değerlendirilmesi (Uşak Üniversitesi Örneği)". Elektronik Sosyal Bilimler Dergisi, 11 (42), 368381 .

22. Demir, G. (2019). "The Role of Emotion Management in Interpersonal Communication: A Research on TeacherStudent Communication". Journal of International Management and Social Researches, 6 (11), 53-67.

23. Polit D.F. and Beck C.T. (2017). Nursing Research: Generating and Assessing Evidence For Nursing Practice. USA: Lippincott Williams \& Wilkins.

24. Guest, G, Bunce, A. and Johnson, L. (2006). "How Many Interviews Are Enough? An Experiment With Data Saturation and Variability". Field Methods, 18 (1), 59-82. https://doi.org/10.1177/1525822X05279903

25. Cutcliffe J.R. and McKenna, H.P, (1999). "Establishing The Credibility of Qualitative Research Findings: The Plot Thickens". Journal of Advanced Nursing, 30 (2), 374-80.
26. Tong, A, Sainsbury, P. and Craig, J. (2007). "Consolidated Criteria For Reporting Qualitative Research (COREQ): A 32-item Chicklist for Interviews and Focus Groups". International Journal for Quality in Health Care, 19 (16), 349-357.

27. Gültekin, M. (2020). "Değişen Toplumda Eğitim ve Öğretmen Nitelikleri”. Anadolu Üniversitesi Eğitim Bilimleri Enstitüsü Dergisi, 10 (1), 654-700.

28. Sharif, F. and Masoumi, S.A. (2005). "Qualitative Study of Nursing Student Experiences Of Clinical Practice”. BMC Nursing, 4 (6), 1-7.

29. Saifan, A.R, Safieh, HA, Milbes, R. and Shibly, R. (2015). "Suggestions to Close the Gap in Nursing Education: Nursing Students' Perspectives". International Journal of Advanced Nursing Studies, 4 (2), 62-68.

30. Factor, E.M.R, Matienzo, E.T, and Guzman, A.B. (2017). "A Square Peg in A Round Hole: Theory-Practice Gap From the Lens of Filipino Student Nurses". Nurse Education Today, 57, 82-87.

31. Sendir, M, Celik, S, Dissiz, M, Güney, R, Acıksoz, S, Kolcu, M. ve Bektemur, G. (2018). "Hemşirelik Eğitimi ve Uygulamasında Yeni Bir Yaklaşım: Hemşirelik Eğitimi ve Uygulamasının Bütünleşmesi”. Hemşirelik Akademik Araştırma Dergisi JAREN, 4 (2), 92-99.

32. Jasemi, M, Whitehead, B, Habibzadeh, H, Zabihi, R.E. and Rezaie, S.A. (2018). "Challenges in the Clinical Education Of the Nursing Profession in Iran: A qualitative study". Nurse Education Today, 67, 21-26.

33. Esmaeili, M, Cheraghi, M.A, Salsali, M. and Ghiyasvandian, S. (2014). "Nursing Students' Expectations Regarding Effective Clinical Education: A Qualitative Study". International Journal of Nursing Practice, 20 (5), 460-467.

34. Kaya, G. ve Yılmaz, S. (2016). “Açık Sorgulamaya Dayalı Öğrenmenin Öğrencilerin Başarısına ve Bilimsel Süreç Becerilerinin Gelişimine Etkisi”. Hacettepe Üniversitesi Eğitim Fakültesi Dergisi, 31 (2), 300-318.

35. Theobald, K.A. and Ramsbotham, J. (2019). "InquiryBased Learning and Clinical Reasoning Scaffolds: An Action Research Project To Support Undergraduate Students' Learning To Think Like A Nurse". Nurse Education in Practice, 38, 59-65.

36. Güneş, F. (2016). "Eğitimde Sorgulamanın Gücü”. Bartın Üniversitesi Eğitim Fakültesi Dergisi. 5 (2), 188-204. 